\title{
HUBUNGAN EFIKASI DIRI DENGAN STRES AKADEMIK PADA MAHASISWA FAKULTAS KEDOKTERAN UNIVERSITAS MALAHAYATI
}

\section{THE RELATION OF SELF-EFFICACY WITH ACADEMIC STRESS IN MEDICAL STUDENT OF MALAHAYATI UNIVERSITY}

\author{
Dewi Avianti $^{1}$, Octa Reni Setiawati ${ }^{2}$, Dewi Lutfianawati ${ }^{3}$, Asri Mutiara Putri ${ }^{4}$ \\ Program Studi Psikologi Universitas Malahayati \\ aviantidewi9@gmail.com
}

Received: $27^{\text {th }}$ October 2021; Revised: $29^{\text {th }}$ January 2021; Accepted: $5^{\text {th }}$ February 2021

\begin{abstract}
Academic stress is the pressure felt by individuals in achieving the expected goals. The phenomenon that occurs is that students are not so sure of their abilities, causing academic stress in achieving their college goals. This study aims to determine the relationship between self-efficacy and academic stress in students of the Faculty of Medicine, Malahayati University, Medical Education Study Program. The hypothesis proposed in this study in that there is a negative relationship between self-efficacy and academic stress among students of the Faculty of Medicine, Malahayati University, Medical Education Study Program. The number of subjects in this study were 101, aged 17 to 22 years, taken from students of the Faculty of Medicine, Malahayati University, Medical Education Study Program class of 2019 with male and female sex. Data collection methods in this study used a self-efficacy scale and a scale of academic stress. The method of analysis in this study used Spearman's product moment analysis method. The results of the data that there is a significant negative relationship between self-efficacy and academic stress in students of the Faculty of Medicine, Malahayati University, Medical Education Study Program.
\end{abstract}

Keywords : Self-Efficacy, Academic Stress

\begin{abstract}
ABSTRAK
Fenomena yang terjadi adalah mahasiswa tidak begitu yakin dengan kemampuan yang dimiliki sehingga menyebabkan stres akademik dalam mencapai tujuan perkuliahannya. Penelitian ini bertujuan untuk mengetahui hubungan efikasi diri dengan stres akademik pada mahasiswa Fakultas Kedokteran Universitas Malahayati. Subjek dalam penelitian ini berjumlah 101, berusia antara 17 sampai 22 tahun diambil dari mahasiswa Fakultas Kedokteran Universitas Malahayati angkatan 2019 dengan jenis kelamin laki-laki dan perempuan. Metode pengumpulan data dalam penelitian ini menggunakan skala efikasi diri dan skala stres akademik, metode analisis dalam penelitian ini menggunakan metode analisis product moment dari Spearman's. Hasil analisis data bahwa terdapat hubungan negatif yang signifikan antara efikasi diri dengan stres akademik pada Mahasiswa Fakultas Kedokteran Universitas Malahayati.
\end{abstract}

Kata kunci: Efikasi Diri, Stres Akademik 


\section{PENDAHULUAN}

Mahasiswa adalah individu yang belajar dan menekuni disiplin ilmu yang ditempuhnya secara mantap, dimana didalam menjalani serangkaian kuliah itu sangat dipengaruhi oleh kemampuan mahasiswa itu sendiri, karena pada kenyataannya diantara mahasiswa ada yang sudah bekerja atau disibukan oleh kegiatan organisasi kemahasiswaan (Ganda, 2004). Menurut As'ari (2007) mahasiswa sering disebut sebagai kelompok cendikiawan dan golongan intelektual yang memegang beban berat di pundak untuk menetukan nasib masa depan bangsa.Transisi dari sekolah menengah atas ke perguruan tinggi melibatkan peralihan memasuki struktur sekolah yang lebih besar dan impersonal, berinteraksi dengan kawan-kawan sebaya yang berasal dari berbagai geografis, dan latar belakang etnis, serta meningkatkan fokus pada pencapaian, performa, dan pengukurannya (Santrock, 2007).

Berbagai permasalahan yang dihadapi oleh mahasiswa baru tak jarang yang menimbulkan stres. Stres secara umum diartikan sebagai kejadian yang mempengaruhi semua dimensi kehidupan manusia dan akan mengganggu individu dalam menyelesaikan masalahnya, mengganggu pandangan hidup, masa depan, dan kesehatannya (Potter \& Perry, 2005). Mahasiswa dengan kapasitasnya yang lebih tinggi diharapkan mampu memahami konsep, dapat memetakan permasalahan dan memilih solusi yang terbaik untuk permasalahan tersebut. Berbagai permasalahan bisa saja timbul dalam diri seorang mahasiswa dalam pelaksanaan aktivitas akademiknya, banyaknya kegiatan yang harus dikerjakan dan dilaksanakan, banyaknya tuntutan yang harus dipenuhi, manajemen waktu yang tidak bagus, dan tugas kuliah menumpuk. Kondisi seperti ini menurut Sarafino (2006) diprediksi dapat memicu stres pada mahasiswa apabila dia tidak mampu memenuhi tuntutan-tuntutan tersebut. 
Stres telah menjadi masalah nyata dalam kehidupan sehari-hari manusia. Sarafino (2006) mendefinisikan stres sebagai suatu kondisi yang disebabkan karena ketidaksesuaiannya antara situasi yang diinginkan dengan keadaan biologis, psikologis atau sistem sosial individu tersebut. Lebih lanjut, Sarafino (2006) mengemukakan stres yang dihadapi individu itu bermacam-macam dan berbeda antar satu individu dengan individu lainnya. Hal ini disebabkan oleh berbagai faktor seperti motivasi, kepribadian, dan intelektual yang terdapat dalam diri individu tersebut.

Dalam bidang akademik, tekanan, dan tuntutan yang bersumber dalam kegiatan akademik disebut stres akademik (Taufik, T., \& Ifdil, I.,2013). Lebih lanjut, Oon (2007) mengungkapkan stres akademik yang dialami mahasiswa terus menerus akan menimbulkan penurunan daya tahan tubuh mahasiswa sehingga mudah mengalami sakit dan penurunan daya tubuh. Mahasiswa mengalami stres sebagai tuntutan kehidupan akademik yang harus dijalani. Stres merupakan suatu kondisi yang disebabkan adanya ketidaksesuaian antara situasi yang diinginkan dengan keadaan biologis dan psikologis atau sistem sosial individu tersebut (Sarafino dan Smith, 2011). Aspek-aspek stres menurut Sarafino dan Timothy (2014) yaitu aspek biologis, kognitif, emosi, dan perilaku sosial.

Stres akademik juga meliputi persepsi mahasiswa terhadap banyaknya pengetahuan yang harus dikuasai. Faktor lain yang dapat menyebabkan stres akademik pada mahasiswa adalah keyakinan. Keyakinan akan kemampuan diri dalam menyelesaikan tugas akademik dapat meningkatkan usaha untuk mencapai tujuan namun juga dapat menjadi penghambat dalam mencapai sasaran. Efikasi diri merupakan suatu kemampuan untuk mengatur dan melaksanakan bagian dari aktivitas yang dibutuhkan agar mencapai tujuan yang diinginkan. Bandura (1999) menyatakan bahwa efikasi diri merupakan keyakinan seseorang akan kemampuannya untuk mengatur dan melaksanakan serangkaian tindakan yang dibutuhkan untuk menghasilkan hasil terbaik. 
Bandura dan Woods (dalam Untung, 2008) menjelaskan bahwa efikasi diri mengacu pada kemampuan individu untuk meningkatkan motivasi, kemampuan kognitif, dan tindakan yang diperlukan dalam menanggapi berbagai situasi yang dihadapinya. Keyakinan dalam diri individu diharapkan mampu membantu mahasiswa dalam menghadapi berbagai situasi yang terjadi dalam dirinya. Bandura (dalam Sarafino, 2006) mengemukakan efikasi diri yang dimiliki individu dapat membuat individu mampu menghadapi berbagai situasi. Dalam situasi sulit, individu dengan efikasi diri yang rendah cenderung mudah menyerah. Sementara individu dengan efikasi diri yang tinggi akan berusaha lebih keras untuk mengatasi tantangan yang ada. Hal ini sesuai dengan pendapat Sarafino (2006) yang mengatakan bahwa individu yang memiliki efikasi diri tinggi akan mengalami tekanan yang lebih rendah ketika berhadapan dengan sumber stres atau stresor. Penelitian ini bertujuan untuk mengetahui hubungan efikasi diri dengan stres akademik pada mahasiswa Fakultas Kedokteran Universitas Malahayati Program Studi Pendidikan Dokter.

\section{METODE PENELITIAN}

Jenis penelitian ini adalah deskriptif kuantitatif dengan menggunakan metode korelasional. Teknik analisis data yang digunakan antara lain, uji prasyarat (normalitas dan linearitas) serta uji hipotesis. Peneliti melakukan uji statistik untuk melihat hubungan efikasi diri dengan stres akademik mahasiswa. Sampel penelitian ditentukan menggunakan teknik Accidental Sampling. Dengan sampel sebanyak 101 mahasiswa Fakultas Kedokteran Universitas Malahayati Program Studi Pendidikan Dokter angkatan 2019. Dalam penelitian ini, peneliti mendapatkan data dari hasil pengisian kuesioner secara on line melalui google form. Setelah data terkumpul, langkah selanjutnya membuat tabel frekuensi dan standar deviasi variabel, memudahkan peneliti dalam menetapkan kriteria pencapaian responden. Adapun kendala dalam hal ini karena masa pandemik Covid- 
19 sehingga peneliti tidak dapat bertatap muka langsung dengan responden guna menyampaikan segala sesuatu yang berkaitan dengan pengisian kuesioner.

\section{HASIL PENELITIAN}

Data yang diperoleh dalam penelitian ini adalah hasil analisis skala yang telah diisi oleh mahasiswa Fakultas Kedokteran Universitas Malahayati Program Studi Pendidikan Dokter angkatan 2019. Skala yang digunakan adalah skala stres akademik dan skala efikasi diri. Skala stres akademik dengan jumlah 40 item dan skala efikasi diri dengan jumlah 30 item. Peneliti mengkategorikan aspek dari variabel penelitian secara empirik menjadi tiga kategori yaitu : rendah, sedang, dan tinggi, seperti yang diuraikan pada tabel sebagai berikut:

\section{Tabel 1. Kategorisasi Skala Stres Akademik}

\begin{tabular}{llll}
\hline Kategori & Kriteria & Frekuensi & Persentase \\
\hline Aspek Perilaku Sosial & & & \\
Rendah & $<25$ & 13 & $13 \%$ \\
Sedang & $26-33$ & 71 & $70 \%$ \\
Tinggi & $>34$ & 17 & $17 \%$ \\
\hline Aspek Biologis & & & \\
Rendah & $<18$ & 9 & $9 \%$ \\
Sedang & $19-26$ & 78 & $77 \%$ \\
Tinggi & $>27$ & 14 & $14 \%$ \\
\hline Aspek Kognitif & & & \\
Rendah & $<19$ & 12 & $12 \%$ \\
Sedang & $20-23$ & 71 & $70 \%$ \\
Tinggi & $>24$ & 18 & $18 \%$ \\
\hline Aspek Emosi & & & \\
Rendah & $<17$ & 6 & $6 \%$ \\
Sedang & $18-23$ & 79 & $78 \%$ \\
Tinggi & $>24$ & 16 & $16 \%$ \\
\hline & & & \\
\hline
\end{tabular}

Sampel dalam penelitian ini yang termasuk dalam aspek perilaku sosial memiliki kategori sedang (70\%), yang termasuk dalam aspek biologis memiliki kategori sedang (77\%), serta yang termasuk 
dalam aspek kognitif memiliki kategori sedang $(70 \%)$ sedangkan yang termasuk dalam aspek emosi memiliki kategori sedang (78\%). 
Tabel 2. Kategorisasi Skala Efikasi Diri

\begin{tabular}{lccc}
\hline Kategori & Kriteria & Frekuensi & Persentase \\
\hline Aspek Strength & & & \\
Rendah & $<29$ & 17 & $17 \%$ \\
Sedang & $30-37$ & 64 & $63 \%$ \\
Tinggi & $>38$ & 20 & $20 \%$ \\
\hline Aspek Generality & & & \\
Rendah & $<22$ & 6 & $6 \%$ \\
Sedang & $23-28$ & 74 & $73 \%$ \\
Tinggi & $>29$ & 21 & $21 \%$ \\
\hline Aspek Level & & & \\
Rendah & $<25$ & 12 & $12 \%$ \\
Sedang & $26-33$ & 72 & $71 \%$ \\
Tinggi & $>34$ & 17 & $17 \%$ \\
\hline
\end{tabular}

Sampel dalam penelitian ini yang termasuk dalam aspek strength memiliki kategori sedang (63\%), yang termasuk dalam aspek generality memiliki kategori sedang (73\%), sedangkan yang termasuk dalam aspek level memiliki kategori sedang (71\%). Selanjutnya adalah uji asumsi, penelitian ini menggunakan uji hipotesis atau uji korelasi, tetapi sebelum melakukan uji hipotesis, perlu dilakukan terlebih dahulu persyaratan analisis, yaitu uji asumsi. Peneliti menggunakan bantuan program SPSS versi 20.0 for windows untuk melakukan uji asumsi.

\section{a. Uji Normalitas}

Berdasarkan 101 kuesioner yang telah diisi oleh responden, maka dilakukan uji normalitas. Uji normalitas yang digunakan pada penelitian ini adalah uji Spearman karena untuk mencari hubungan atau untuk 
menguji signifikansi hipotesis. Sebaran data berada pada kurva normal jika $p>0,05$ sedangkan kurva tidak normal jika $\mathrm{p}<0,05$. Uji normalitas dapat dilihat pada table berikut :

Tabel 3. Uji Normalitas Stres Akademik

\begin{tabular}{|l|r|r|r|r|r|r|}
\multicolumn{9}{|c|}{ Tests of Normality } \\
\hline \multirow{2}{*}{} & \multicolumn{2}{|c|}{ Kolmogorov-Smirnov ${ }^{\mathrm{a}}$} & \multicolumn{3}{|c|}{ Shapiro-Wilk } \\
\cline { 2 - 7 } & Statistic & df & Sig. & Statistic & df & Sig. \\
\hline $\begin{array}{l}\text { STRES } \\
\text { AKADEMIK }\end{array}$ & .106 & 101 & .007 & .972 & 101 & .032 \\
\hline
\end{tabular}

a. Lilliefors Significance Correction

\section{Tabel 4. Uji Normalitas Efikasi Diri}

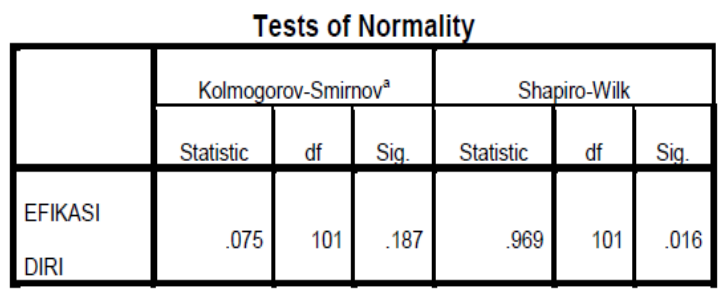

a. Lilliefors Significance Correction

Hasil uji normalitas pada variabel Stres akademik $\mathrm{P}=0,032$, sedangkan pada variabel Efikasi diri $\mathrm{P}=$ 0,016 dengan demikian karena data tidak terdistribusi normal maka akan dilakukan uji Spearman. Berikutnya adalah hasil uji linearitas, seperti yang terlihat pada tabel berikut:

\section{Tabel 5. Linearitas Stres akademik dan efikasi diri}

\begin{tabular}{|c|c|c|c|c|c|c|c|}
\hline & & & $\begin{array}{l}\text { Sum of } \\
\text { Squares }\end{array}$ & $\mathrm{df}$ & $\begin{array}{l}\text { Mean } \\
\text { Square }\end{array}$ & $\mathrm{F}$ & Sig. \\
\hline $\begin{array}{l}\text { EFIKASI DIRI } \\
\text { *STRES } \\
\text { AKADEMIK }\end{array}$ & $\begin{array}{l}\text { Between } \\
\text { Groups } \\
\text { Within Groups } \\
\text { Total }\end{array}$ & $\begin{array}{l}\text { (Combined) } \\
\text { Linearity } \\
\text { Deviation } \\
\text { from } \\
\text { Linearity }\end{array}$ & $\begin{array}{l}4363.585 \\
3040.150 \\
1323.435 \\
3827.663 \\
8191.248\end{array}$ & $\begin{array}{r}32 \\
1 \\
31 \\
68 \\
10 \\
\end{array}$ & $\begin{array}{r}136.362 \\
3040.150 \\
42.691 \\
56.289\end{array}$ & $\begin{array}{r}2.423 \\
54.010 \\
.758\end{array}$ & $\begin{array}{l}.001 \\
.000 \\
.800\end{array}$ \\
\hline
\end{tabular}


Berdasarkan tabel diatas menunjukkan bahwa korelasi antara stres akademik dan efikasi diri pada Linearity diperoleh nilai $\mathrm{F}=54,010$ dengan $\mathrm{p}=0,000(\mathrm{p}<0,05)$ dan pada Deviation from Linearity diperoleh nilai $\mathrm{F}=0,758$ dengan $\mathrm{p}=0,800(\mathrm{p}>0,05)$. Hal ini menunjukkan bahwa korelasi antara stres akademik dan efikasi diri bersifat linear secara signifikan.

Untuk menguji hipotesis, peneliti menggunakan teknik korelasi Spearman. Hipotesis yang diajukan dalam penelitian ini adalah adanya hubungan negatif dan signifikan antara stres akademik dengan efikasi diri pada mahasiswa, seperti pada tabel berikut :

Tabel 6. Korelasi antara stres akademik dan efikasi diri

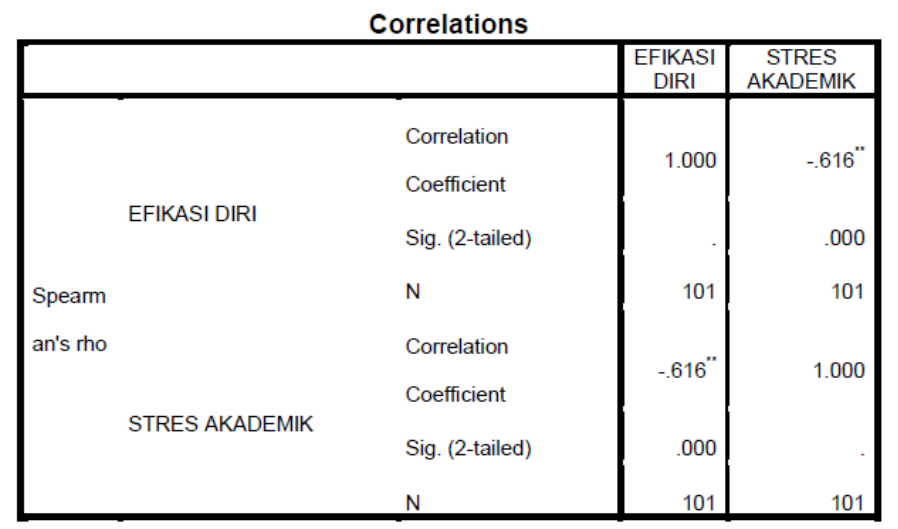

**. Correlation is significant at the 0.01 level (2-tailed).

Berdasarkan tabel diatas hasil analisis data menunjukkan nilai koefisien $r=-0,616$ dengan $p=0,000(p<$ $0,05)$.

\section{DISKUSI}

Dari hasil penelitian dapat diperoleh data yang ditunjukan oleh tabel 1 dan tabel 2 bahwa kategorisasi variabel efikasi diri dan kategorisasi variabel stres akademik berbanding lurus, dapat dikatakan bahwa mahasiswa yang memiliki efikasi diri yang tinggi dapat terhindar dari kondisi stres akademik. Menurut Bandura (dalam Ghufron \& Risnawita, 2010) mengatakan bahwa persepsi terhadap efikasi diri pada setiap individu berkembang dari pencapaian secara berangsur-angsur akan kemampuan dan pengalaman tertentu secara 
terus menerus. Bandura (dalam Ghufron \& Risnawita, 2010) efikasi diri dapat ditumbuhkan dan dipelajari, salah satunya melalui pengalaman menguasai sesuatu (master experience).

Sumber informasi ini memberikan pengaruh besar pada efikasi diri individu karena didasarkan pada pengalaman-pengalaman pribadi individu secara nyata yang berupa keberhasilan dan kegagalan. Pengalaman keberhasilan akan menaikkan efikasi diri individu, sedangkan pengalaman kegagalan akan menurunkannya. Setelah efikasi diri yang kuat berkembang melalui serangkaian keberhasilan, dampak negatif dari kegagalankegagalan yang umum akan terkurangi. Bahkan, kemudian kegagalan diatasi dengan usaha-usaha tertentu yang dapat memperkuat motivasi diri apabila seseorang menemukan lewat pengalaman bahwa hambatan tersulit pun dapat diatasi melalui usaha yang terus menerus.

Hasil hipotesis menunjukkan bahwa terdapat hubungan negatif yang signifikan antara stres akademik pada mahasiswa. Hal ini terbukti dari hasil Spearman Correlation yang menunjukkan bahwa terdapat hubungan negatif yang signifikan antara stres akademik dengan efikasi diri pada mahasiswa $(-0,616)$. Dengan demikian menunjukkan semakin tinggi efikasi diri mahasiswa maka semakin rendah stres akademiknya. Sebaliknya semakin rendah efikasi diri pada mahasiswa maka semakin tinggi stres akademiknya. Hasil penelitian ini sejalan dengan hasil penelitian yang telah dilakukan oleh Nadirawati, (2018) bahwa ada hubungan negatif antara efikasi diri dengan stres akademik yaitu semakin tinggi efikasi diri mahasiswa maka semakin rendah stres akademik yang akan terjadi.

\section{KESIMPULAN DAN SARAN}

Berdasarkan hasil penelitian, dapat disimpulkan bahwa kategori stres akademik yang tertinggi yaitu kategori stres akademik sedang pada aspek emosi sedangkan kategori efikasi diri yang tertinggi yaitu kategori efikasi diri sedang pada aspek generality. Efikasi diri memiliki peran penting dalam diri individu sebagai pengelola persepsi diri dalam menghadapi tantangan perkuliahan. Peningkatan motivasi, meningkatkan kemampuan, dan mempersiapkan diri menghadapi berbagai kondisi yang dapat memicu stres akademik 
mahasiswa. Dari hasil penelitian ditemukan bahwa stres akademik dapat meningkatkan efikasi diri mahasiswa dikarenakan tekanan yang dihasilkan dari kondisi stres akademik dapat membentuk persepsi mahasiswa siap menghadapi tantangan yang semakin besar kedepannya. Hal ini membuktikan terdapat hubungan antara efikasi diri dengan stres akademik pada mahasiswa Fakultas Kedokteran Universitas Malahayati.

Hasil penelitian menunjukkan efikasi diri dan stres akademik memiliki kategori sedang, bagi peneliti selanjutnya yang tertarik untuk meneliti dengan permasalahan yang sejenis, diharapkan dapat lebih menggali aspek efikasi diri seperti dimensi tingkat (level), dimensi kekuatan (strength), dan dimensi generalisasi (generality) dan diharapkan dapat menurunkan stres akademik. Kepada mahasiswa Fakultas Kedokteran Universitas Malahayati Program Studi Pendidikan Dokter untuk terus berusaha meningkatkan keyakinannya dalam menghadapi berbagai problem selama kuliah dengan cara memperbanyak sharing atau diskusi dengan teman sebaya, adik atau kakak tingkat, banyak diskusi dengan dosen, serta rajin mengikuti seminar atau kegiatan yang dapat meningkatkan efikasi diri sehingga dapat menekan terjadinya stres akademik.

\section{DAFTAR PUSTAKA}

As’ari, D. K. (2007). Mengenal Mahasiswa dan Seputar Organisasinya. Jakarta: Pena Deni.

Bandura, A., Freeman, W. H., \& Lightsey, R. (1999). Self-efficacy: The exercise of control.

Ganda, Y. (2004). Petunjuk Praktis Cara Mahasiswa Belajar di Perguruan Tinggi. Jakarta: Grasindo.

Ghufron, NM. \& RS Risnawita. (2010). Teori-teori Psikologi. Yogjakarta: Ar-Ruzz Media.

Nadirawati,R,( 2018). Hubungan Efikasi Diri Dengan Stres Akademik Pada Mahasiswa Baru Fakultas Keperawatan Universitas Jember (Skripsi) (diunduh 4 Juni 2020 dihttps://repository.unej.ac.id).

Oon, A, N. (2007). Handling Study Stress. Jakarta: Alex Media Komputindo.

Potter, PA \& Perry AG. (2005). Buku Ajar Fundamental Keperawatan: Konsep, Proses, dan Praktik. Edisi 4 Volume 1, EGC, Jakarta.

Santrock, JW. (2007). Life-Span Development. Jakarta: Erlangga.

Sarafino, (2006). Health Psychology: Biopsychosocial Interaction.USA: John Waley \& Sons, In.

Sarafino, E. P. \& Smith, T. W. (2011). Health psychology biopsychological interaction.

Diunduh dari http://gen.lib.rus.ec/book/index.php?md5=0D09C51C33BC045CFC4C2

Sarafino, E.P. \& Timothy W.S. (2014). Health Psychology: Biopsychosocial Interactions 8th edition. United States of America

Taufik, T., \& Ifdil, I. (2013). Kondisi Stres Akademik Siswa SMA Negeri di Kota Padang. Jurnal Konseling dan Pendidikan, 1(2), 143-150.

Untung, M. (2008). Pengaruh Self-Efficacy terhadap Resiliensi pada Mahasiswa Fakultas Psikologi Universitas Islam Negeri (UIN) Malang". Jurnal Psikologi UIN Malang. 